\title{
Eksistensi Bank Aceh Pasca Konversi Terhadap Kesejahteraan Masyarakat Aceh
}

\author{
'Yoesrizal Muhammad Yoesoef, ${ }^{2}$ Khairisma \\ ${ }^{1}$ Institut Agama Islam Negeri Lhokseumawe, ${ }^{2}$ Bangor University \\ e-mail: 1yoesrizal@iainlhokseumawe.ac.id, 2khairismazainuddin@gmail.com \\ ${ }^{1} \mathrm{Jl}$. Medan-Banda Aceh, Kota Lhokseumawe, ${ }^{2}$ Bangor LL57 2DG, United Kingdom
}

\begin{abstract}
Abstrak
Penelitian ini bertujuan untuk mengetahui perkembangan produk pembiayaan Bank Aceh dan pengaruh produk pembiayaan Bank Aceh setelah dikonversi ke sistem Syariah terhadap kesejahteraan masyarakat Aceh. Penelitian ini merupakan jenis penelitian gabungan dengan pendekatan kuantitatif menggunakan sampel 101 orang dari jumlah nasabah Bank Aceh. Hasil penelitian memnyimpulkan bahwa,pertama, Bank Acehtelah mempunyai produkproduk pembiayaan murabahah (produk pembiayaan multi guna, konsumer, pembiayaan pensiun, pembiayaan mikro); pembiayaan musyarakah (pembiayaan rekening koran syariah, pembiayaan kontruksi dan pembiayaan mikro) dan pembiayaan mudharabah. Kedua, eksistensi Bank Aceh setelah dikonversi menjadi bank syariah berpengaruh positif terhadap kesejahteraan masyarakat Aceh. Selain itu, produk pembiayaan murabahanmerupakan produk yang paling banyak diminati sebanyak 64\%, nilai ini berbanding terbalik dengan akad kerjasama produk lainnya. Namun, nilai positif yang diberikan kepada Bank Aceh menunjukkan bahwa produk murabahah dapat meningkatkan kesejahteraan masyarakat Aceh meskipun banyak masyarakat berminat terhadap pembiayaan mudharabah dan qardul hasan.
\end{abstract}

\section{Kata Kunci: Eksistensi, Konversi, Bank Aceh Syariah, Kesejahteraan}

\begin{abstract}
Abstrac
The purpose of this research is toknow Aceh Bank financing product development and to explore Aceh Bank financing product after converting to the sharia system for Acehnese prosperity.Thi research is a combination research with qualitative research approach by 101 sample. The research result shows that, first Aceh Bank has had murabahah financing (multifunction financing product, consumer, pension financing, micro financing); musyarakah financing (sharia bank statement financing, islamic real estate financing, and micro financing); and mudharabah financing. The second. This research also found that Aceh bank Existence after converting has become a bank which has given a positive influence for Acehnese prosperity.Furthermore, murabahah is the most widely used financing product at $64 \%$. However, the given positivity to Sharia Aceh Bank shows that murabahah product has resulted in Acehnese prosperity even though a lot of people prefer to take mudharabah and qardul hasan financing product.
\end{abstract}

Keywords: Existence, Conversion, Sharia Aceh Bank, Prosperity 


\section{Eksistensi Bank Aceh Pasca Konversi Terhadap Kesejahteraan Masyarakat Aceh}

Yoesrizal Muhammad Yoesoef, Khairisma

\section{Pendahuluan}

Menurut laporan Badan Pusat Statistik (BPS) yang dirangkum pada tahun 2010, Aceh tercatat sebagai provinsi dengan jumlah penduduk muslim terbanyak yaitu 98,19\% dari 4.413.244 jiwa (BPS Aceh, 2019). Berkaitan dengan perekonomian, perbankan merupakan salah satu wadah bagi masyarakat untuk meningkatkan pertumbuhan perekonomian dan taraf hidup mereka dengan cara menghimpun dana dari masyarakat yang berkecukupan untuk kemudian menyalurkannya kembali kepada masyarakat lainnya dalam bentuk pinjaman modal kerja untuk meningkatkan kesejahteraan hidup masyarakat yang tingkat perekonomiannya menengah ke bawah(Anwar and Said, 2019).Jika disikapi pergerakan perekonomian Aceh, sudah sepatutnya bank hadir sebagai solusi di tengah-tengah masyarakat, pasalnya angka kemiskinan di Aceh tergolong cukup tinggi yaitu 831 ribu orang (15,68 persen) dari total penduduk Aceh(BPS Aceh, 2018).

Mulai dari awal didirikannya perbankan di Indonesia, tidak terkecuali Aceh juga mendapatkan penerapan yang sama dalam penyajian perbankan di setiap provinsi(Al Kautsar et al., 2019). Kita bisa mendapati berbagai macam bank di Aceh seperti Bank Mandiri, Bank Negara Indonesia (BNI), Bank Central Asia (BCA), Bank Rakyat Indonesia (BRI) dan Bank Bukopin bahkan ada juga bank hasil kerjasama dengan pihak asing seperti bank CIMB NIAGA yang menjadi lembaga intermediasi untuk rakyat Aceh(OJK, 2019).

Selain bank-bank nasional diatas, Pemerintah Indonesia telah mencanangkan pendirian bank-bank daerah atau lebih dikenal dengan sebutan Bank Pembangunan Daerah (BPD) yang ketentuannya diatur sejak UU No. 13/1962, dimana selain bertujuan untuk meningkatkan taraf hidup masyarakat, juga dipersiapkan sebagai tempat penyimpanana kas daerah serta menjadi sumber untuk pendapatan asli daerah sehingga sangat krusial perannya dalam pembangunan regional, karena keberadaannya dapat menjalankan peranperan yang tidak dapat dilakukan oleh bank-bank swasta dengan menyediakan pembiayaan guna memperbaiki perekonomian di daerahnya(Hasan et al., 2010). Hal ini ditegaskan dalam surat keputusan Kementrerian dalam negeri Republik Indonesia No. 62 Tahun 1999 tentang pedoman organisasi dan tata kerja bank pembangunan daerah pasal 2 bahwa Bank dibangun untuk mengembangkan ekonomidan menggerakkan pembangunan daerah melalui kegiatan Bank sebagai Bank("Kepmendagri", 1999).

Merespon UU No. 13/1962 di atas, Pemerintah Provinsi Aceh mengeluarkan Peraturan Daerah (Perda) No. 12 tahun 1963 yang menjadi landasan hukum berdirinya Bank Pembangunan Daerah Istimewa Aceh dan yang lebih dikenal dengan Bank Aceh("Laporan Tahunan", 2018).Tidak berbeda dengan bank-bank konvensional pada umumnya, bank Aceh menjalankan perannya sebagai badan intermediasi non Syariah dan 
pada tahun 2004, bank Indonesia memberikan izin untuk menjalankan perbankan dengan prinsip Syariah (Mutia and Aswadi, 2017).Pada saat itu bank belum sepenuhnya menjadi Syariah, prinsip yang digunakan oleh Bank Aceh saat itu adalah dual banking sistem.Dual banking system adalah sistem perbankan yang mengacu pada bank conventional dan bank Islam (Farlian and Nuraidar, 2017). Ketika bank Islam diperkenalkan, strategi dasar adalah salah satu replikasi yang pada dasarnya menggunakan aplikasi dana bank konvensional menjadi produk yang dapat diterima islam(Khalidin, 2017). Dengan kata lain, ada dua jenis sistem di dalam satu instansi perbankan contohnya BRI, ada BRI yang bergerak dalam ruang lingkup konventional dan BRI Syariah, bank Mandiri dan bank Mandiri Syariah dan dalam hal ini yaitu Bank Aceh (yang bergerak secara konventional dan Bank Aceh Syariah (bergerak dalam tatanan hukumIslam).

Setelah beberapa lama praktik Syariah di Bank Aceh hanya diterapkan di unit Syariahnya, Pemerintah Aceh akhirnya mencanangkan agar Bank Aceh hanya menjalankan aktivitas yang keseluruhan sesuai dengan Syariah. Maka Mulai tanggal 9 september 2016 seluruh sistem operasional Bank Aceh diganti kepada sistem Syariah secara keseluruhan(Bank Aceh, 2018). Perjalanan sistem Syariah di perbankan syariah Indonesia ternyata hasil yang diperoleh belum sepenuhnya sesuai dengan ekspektasi masyarakat (Yulianti, 2015). Menurut Dwi Ana Ratna Utami, masyarakat menganggap bahwa Bank Syariah belum Islami karena sistem keuangan dan operasionalnya masih bercampur dengan sistem Bank konventional berbasis bunga atau riba(Utami, 2017). Begitu juga pemikiran masyarakat Aceh yang menganggap Bank Aceh Syariah belum dapat sepenuhnya menjalankan sistem perbankan syariah(Kismawadi and Al Muddatstsir, 2018).

Berbagai usaha dalam perubahan sistem Bank Aceh konventional menjadi Syariah sepenuhnya dilakukan demi mencapai kepuasan masyarakat Aceh untuk mematuhi Syariah Allah yaitu tidak memakan riba.Hal ini selaras dengan salah satu tujuan pembentukan Lembaga perbankan sebagai Lembaga intermediasi untuk membantu orang-orang miskin dan tidak hanya sekedar mengganti wajah perbankan menjadi 100\% Syariah demi meraup keuntungan(Purwanto, 2018).

Dalam observasi awal, peneliti mengkaji laporan keuangan Bank Aceh Syariah yang menunjukkan bahwa pembiayaan yang diberikan kepada masyarakat Aceh masih sangat sedikit.Ini menjadi dilema bagi masyarakat Aceh dengan tingkat kemiskinannya yang sangat memprihatinkan dan sudah selayaknya Bank memberikan pelayanan berupa pembiayaan untuk mengurangi angka kemiskinan. Pasalnya dalam laporan keuangan ditemukan fakta menarik bahwa Bank Aceh dengan dana syirkah kontemporer Rp. 5·590.179.0oo.ooo dan didukung oleh APBA yang cukup tinggi yaitu Rp 14.765.000.000.000 pada tahun 2017, hanya memberikan pembiayaan kepada masyarakat Aceh sebesar 23\% dari total dana 


\section{Eksistensi Bank Aceh Pasca Konversi Terhadap \\ Kesejahteraan Masyarakat Aceh}

Yoesrizal Muhammad Yoesoef, Khairisma

syirkah kontemporer. Lebih lanjut jika ditelusuri dari jumlah aset 2017, terlihat bahwa pembiayaan yang diberikan Bank Aceh Syariah kepada masyarakat hanyalah berupa musyarakah dan sebagian kecil Qardhul Hasan("Laporan Tahunan", 2017), begitu juga yang disampaikan oleh seorang staff senior bagian pembiayaan PT. BASKC. Merdeka Lhokseumawe bahwa tidak adanya produk pembiayaan mudharabah yang disalurkan kepada nasabah dikarenakan resikonya sangat tinggi (Zulkahiri, 2019).Padahal jika ditelusuri lebih lanjut, pembiayaan yang sangat dibutuhkan oleh masyarakat Aceh adalah mudharabah dan qardhul hasan karena dengan ekonomi yang sangat rendah sangat tidak memungkinkan bagi masyarakat Aceh untuk memiliki sejumlah modal dan bergabung dengan perbankan untuk melakukan aktivitas musyarakah(Sabrina and Majid, 2019).Selain itu dari Data Keuangan Unaudited 2018, Bank Aceh Syariah berhasil menghasilkan kinerja keuangan yang cukup baik, perolehan laba sebelum pajak mencapai setengah triliun lebih (Rp 540 miliar). Sementara, penerimaan dari dana pihak ketiga juga berhasil mendongkrak catatan kinerja usaha sebesar Rp 18.39 triliun. Penyaluran dana untuk pembiayaan juga meningkat dan tumbuh positif dengan posisi akhir pembiayaan mencapai Rp 13.36 triliun. Hasilnya, ditengah ketatnya kompetisi usaha di sektor keuangan tadi, Bank Aceh justru mencatat dan mampu mencapai akselerasi tinggi dengan capaian pertumbuhan aset menembus $\mathrm{Rp} 23,20$ triliun dalam dua tahun pasca konversi(ModusAceh.co, 2019). Akan tetapi prestasi di atas berbanding terbalik dengan tingginya data kemiskinan di provinsi Aceh yang menempati rangkit tertinggi di Pulau Sumatera(Saputra, 2019). Sehingga peneliti berasusmi bahwa masyarakat menganggap Bank Aceh Syariah belum menjadi sarana untuk perbaikan kondisi ekonomi masyarakat Aceh.

Penelitian ini memfokuskan pada pengaruh Bank Aceh setelah dikonversi menjadi bank syariah terhadap kesejahteraan masyarakat Aceh.Penelitian ini juga dilakukan karena didukung oleh realita dimana masih banyak masyarakat Aceh yang beranggapan bahwa perbankan Syariah tidak memiliki perbedaan dengan bank-bank konvensional lainnya dalam penerapan prinsip Syariah.Dari pendahuluan di atas, maka peneliti mempertanyakan Bagaimana Pengaruh produk pembiayaan Bank Aceh setelah dikonversi ke sistem Syariah terhadap Kesejahteraan masyarakat Aceh?

\section{Tinjauan Teoritik}

\section{Eksistensi}

Eksistensi adalah suatu kata yang berasal dari kata exixtere yang berarti ada, timbul dan muncul (Sugiono et al., 2008). Di dalam kamus filsafat dijelaskan bahwa eksistensi memiliki makna yaitu apa yang ada, sesuatu yang memiliki aktualitas, segala sesuatu yang 
dialami dan menekankan bahwa sesuatu itu ada sertamemiliki kesempurnaan(Bagus, 1996). Menurut Abidin zaenal dalam bukunya yang berjudul Analisis Eksistensial, eksistensi adalah suatu proses dari sesuatu yang ada dan tidak bersifat kaku dan tergantung pada kemampuan untuk menerapkan berbagai potensi(Abididn, 2007). Menurut Karl Japers berpendapat bahwa eksistensi adalah suatu istilah yang digunakan untuk mejelaskan keunikan sesorang sehingga orang tersebut mampu untuk bertahan hidup dengan jati diri yang dimilikinya (Jaspers, 1995).Oleh karenanya eksistensi menghasilkan pengaruh terhadap sesuatu sebagai jati diri yang diciptakannya.

\section{Konversi Perbankan}

Dalam Kamus Bahasa Indonesia , "konversi" didefenisikan sebagai perubahan dari satu sistem pengetahuan ke sistem yang lain atau dapat juga dimaknai perubahan dari satu bentuk ke bentuk yang lain(Sugono et al., 2008). Dalam Pasal 2 Ayat (1) ditegaskan bahwa bank konvensional dapat melakukan perubahan kegiatan usaha menjadi bank syariah.Kapasitas Bank Indonesia dalam pengaturan konversi hanya terkait dengan entitas badan usaha sebagai mana dimaksud dalam PBI No.8/3/PBI/2006, tidak termasuk konversi produknya. Bank dalam jangka waktu satu tahun diwajibkan menyelesaikan keberatankeberatan dari nasabah pengguna produk bank yang bersangkutan("Peraturan Bank Indonesia", 2006).

Proses dan teknis Konversi bank konvensional menjadi bank syariah belum dijumpai dalam Undang-Undang Nomor 10 Tahun 1998 tentang perubahan atas Undang-Undang Nomor 7 Tahun 1992 tentang Perbankan. Ketentuan mengenai konversi secara teknis diatur dalam pasal 2 PBI No. 8/3/PBI/2006 yang intinya menyatakan bahwa bank hanya dapat mengubah kegiatan usahanya menjadi bank yang melaksanakan kegiatan usaha berdasarkan prinsip syariah dengan izin Gubernur Bank Indonesia, di mana rencana tersebut wajib dicantumkan dalam rencana bisnis bank. PBI No.8/3/PBI/2006 sebagaimana tersebut diatas, saat ini telah dicabut dengan PBI No. 11/15/PBI/2009 tentang perubahan kegiatan usaha bank konvensional menjadi syariah. Dalam Pasal 2 Ayat (1) ditegaskan bahwa bank bank konvensional dapat memelakukan perubahan kegiatan usaha menjadi bank syariah.Kemudian Ayat (2) menegaskan bahwa perubahan kegiatan usaha bank konvensional menjadi bank syariah dapat dilakukan oleh Bank Umum Konvensional menjadi Bank Umum Syariah dan Bank Perkreditan Rakyat menjadi Bank Pembiayaan Rakyat Syariah ("Peraturan Bank Indonesia", 2006).

Bank konvensional yang akan melakukan perubahan kegiatan usaha menjadi bank syariah harus melaksanakan beberapa hal, yaitu:

1. Melakukan penyesuaian anggarandasar; 


\section{Eksistensi Bank Aceh Pasca Konversi Terhadap \\ Kesejahteraan Masyarakat Aceh}

Yoesrizal Muhammad Yoesoef, Khairisma

2. Melaksanakan dan memenuhi persyaratan permodalan

3. Memenuhi penyesuaianPersyaratan direksi dan dewan komisaris

4. Membentuk DPS (Dewan Pengawas Syariah)

5. Melakukan penyajian laporan keuangan awal sebagai sebuah bank syariah("Peraturan Bank Indonesia", 2006)

\section{Bank Aceh Syariah}

Perseroan Terbatas (PT) Bank Aceh Syariah (BAS) merupakan bank yang dibangun oleh pemerintah guna meningkatkan perekonomian daerah (Suherman, 2018). Bank Aceh sah diresmikan melaksanakan sistem Syariah secara keseluruhan dalam manajemen BAS pada tahun 2016. Dengan pertumbuhan asset yang baik, Bank Aceh dianggap menjadi salah satu bank terbaik dalam kategori Bank Pembangunan Daerah (BPD)("Laporan Tahunan", 2012).

\section{Hipotesis Penelitian}

Dalam penelitian ini terdapat 2 variabel: variabel independen adalah pembiayaan Bank Aceh Syariah dan variabel dependenadalah Kesejahteraan. Variabel pembiayaan Bank Aceh Syariah sebagai variabel (X) dan variable Kesejahteraan sebagai variabel (Y). Hipotesis penelitian yang diajukan peneliti adalah:

a. Ho: Pembiayaan (X) tidak berpengaruh terhadap kesejahteraan masyarakat Aceh (Y).

b. Ha:Pembiayaan (X) berpengaruh terhadap kesejahteraan masyarakat Aceh (Y) (Ghozali, 2006).

\section{Metode Penelitian}

Penelitian ini berupa penelitian empiris (penelitian lapangan) dengan pendekatan kuantitatif, menguraikan secara terperinci mengenai materi pembiayaan terutama berkenaan dengan eksistensi dana pembiayaan PT. BAS Banda Aceh, Lhokseumawe dan Aceh Utara setelah konversi terhadap kesejahteraan masyarakat. Metode pengumpulan data yang dilakukan oleh peneliti adalah: Metode Angket (quesioner) dengan memberikan beberapa pertanyaan tertulis untuk dijawab oleh 101 masyarakat Sebagai sampel yang didapat memakai rumus slovin dengan presisi 10\%, sampel tersebut didapat dari jumlah nasabah dari seluruh Bank Aceh yaitu 1.600.0oo jiwa(Bank Aceh, 2017).

Selanjutnya, dalam penelitian ini juga diperlukan studi dokumen terhadap laporan penelitian, jurnal, artikel makalah serta hasil seminar-seminar ilmiah yang berkaitan dengan materi perbankan Syariah dan produk-produknya. Selain data quisioner, peneliti juga 
mewawancarai petugas yang berwenang di bank aceh Syariah yaitu Ibu Khairunnisa petugas divisi SDI di PT. Bank Aceh Syariah Kantor Pusat di Banda Aceh, Bapak Zulkhairi, Staff Senior Bagian Pembiayaan Bank Aceh Syariah Kantor Cabang Merdeka Lhokseumawe dan Bapak Ahmad Firman Staff Senior Bagian Pembiayaan Bank Aceh Syariah Kantor cabang Pembantu Panton Labu mengenai produk-produk pembiayaan dan hal-hal yang berhubungan dengan eksistensi Bank Aceh Syariah Pasca Konversi terhadap kesejahteraan masyarakat.

\section{Hasil dan Pembahasan}

\section{Hasil Penelitian}

Subjek/narasumber dalam penelitian ini adalah masyarakat Aceh dari tiga daerah berbeda yaitu Lhokseumawe, Aceh Utara dan Banda Aceh.Penelitian ini berhasil mendapatlan sampel sebanyak 101 responden/narasumber, sebagian besar adalah narasumber laki-laki yaitu sebanyak 66 Narasumber (65,7\%) dan 35 Narasumber/responden perempuan $(34,3 \%)$.

a. Pendidikan Terakhir

Tabel 1. Pendidikan Terakhir

\begin{tabular}{cc}
\hline SMA/MA & $5 \%$ \\
S1 & $43,6 \%$ \\
S2 & 35,6 \\
S3 & 8,9 \\
D3 & $4 \%$ \\
No Information & $3 \%$ \\
\hline
\end{tabular}

Tabel di atas memberi informasi bahwa koresponden yang telah mengisi kuisioner yang merupakan tamatan SMA/MA sebanyak (5 orang), S1 (44 orang), S2 (36 orang), S3 (9 orang), D3 (4 orang) dan yang tidak memberikan informasi sebanyak 3 orang.

b. Status Dengan Bank Aceh

Tabel 2.Status_Dengan_BAS

\begin{tabular}{ccccc}
\hline & & \multicolumn{3}{c}{ Valid } \\
Nasabah & 92 & 91.1 & 91.1 & 91.1 \\
2 & 9 & 8.9 & 8.9 & 100 \\
Total & 101 & 100 & 100 & \\
\hline
\end{tabular}




\section{Eksistensi Bank Aceh Pasca Konversi Terhadap}

Kesejahteraan Masyarakat Aceh

Yoesrizal Muhammad Yoesoef, Khairisma

Tabel 3. Ambil tidaknya Pembiyaan di BAS

\begin{tabular}{ccccc}
\hline & Frequenc & \multicolumn{3}{c}{ Valid } \\
Ya & y & Percent & Percent & Cumulative Percent \\
2 & 72 & 71.3 & 71.3 & 71.3 \\
Total & 29 & 28.7 & 28.7 & 100 \\
\hline
\end{tabular}

Dari 2 tabel di atas dapat dilihat bahwa koresponden yang juga menjadi nasabah Bank Aceh ialah sebesar 91,1\% dan yang no nasabah sebesar 8,9\%, sedangkan yang mengambil pembiayaan ialah 72 orang dari total 101 koresponden.

c. Pembiyaan yang Diambil

Peneliti mefokuskan penelitian terhadap pembiayan-pembiayaan yang tersedia pada Bank Aceh Syariah (BAS) yaitu Pembiayaan mudharabah, musyarakah, murabahah, ijarah dan qardul hasan sebagai akad yang sedang dilakukan pernah dilakukan oleh koresponden dengan PT. BAS, rinciannya adalah sebagai berikut:

Persentase

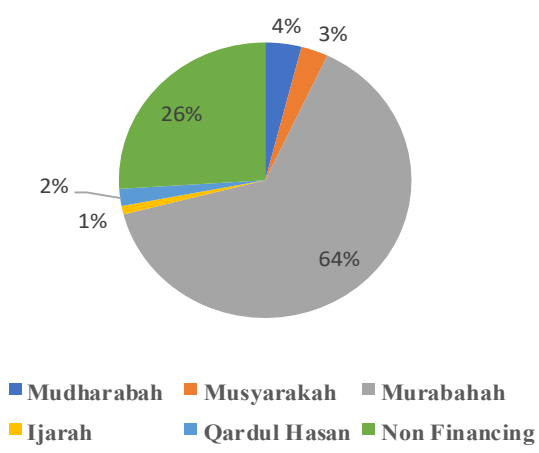

Gambar 1. Persentase Pembiyaan yang Diambil Responden 


\section{a) Uji Validitas}

a. Uji validitas variabel $\mathrm{X}$

Tabel 4. Hasil Uji validitas variabel $X$

\begin{tabular}{|c|c|c|c|c|}
\hline No Item & Rhitung & rtabel 5\% (N-2) & Sig. & Kriteria \\
\hline 1 & 0,860 & 0,1956 & 0,000 & Valid \\
2 & 0,823 & 0,1956 & 0,000 & Valid \\
3 & 0,768 & 0,1956 & 0,000 & Valid \\
4 & 0,600 & 0,1956 & 0,000 & Valid \\
5 & 0,752 & 0,1956 & 0,000 & Valid \\
6 & 0,804 & 0,1956 & 0,000 & Valid \\
7 & 0,827 & 0,1956 & 0,000 & Valid \\
8 & 0,823 & 0,1956 & 0,000 & Valid \\
\hline
\end{tabular}

Berdasarkan tabel di atas dapat disimpulkan bahwa seluruh pertanyaan untuk variabel X (Bank Aceh Pasca Konversi) adalah valid, karena nilai r-hitung (Corrected Item-Total Correlation) > r-tabel yang 0,1956, begitu juga jika dilihat dari keseluruhan nilai signifikansi yang menunjukkan lebih kecil dari o,05.

b. Uji validitas terhadap variabel Y

Tabel 5. Hasil Uji Validitas Variabel (Y)

\begin{tabular}{|c|c|c|c|c|}
\hline No Item & Rhitung & rtabel 5\% (N-2) & Sig. & Kriteria \\
\hline 1 & 0,842 & 0,1956 & 0,000 & Valid \\
\hline 2 & 0,885 & 0,1956 & 0,000 & Valid \\
\hline 3 & 0,831 & 0,1956 & 0,000 & Valid \\
\hline 4 & 0,867 & 0,1956 & 0,000 & Valid \\
\hline 5 & 0,776 & 0,1956 & 0,000 & Valid \\
\hline 6 & 0,286 & 0,1956 & 0,004 & Valid \\
\hline 7 & 0,863 & 0,1956 & 0,000 & Valid \\
\hline
\end{tabular}

Tabel di atas menunjukkan bahwa ketujuh pertanyaan yang diajukan sebagai variabel Y dalam mengukur kesejahteraan masyarakat Aceh adalah valid, karena nilai $\mathrm{r}$ hitung (Corrected Item-Total Correlation) > r-tabel yang 0,1956, begitu juga jika dilihat dari keseluruhan nilai signifikansi yang menunjukkan lebih kecil dari 0,05. 


\section{Eksistensi Bank Aceh Pasca Konversi Terhadap}

Kesejahteraan Masyarakat Aceh

Yoesrizal Muhammad Yoesoef, Khairisma

\section{b) Uji Reliabilitas}

Tabel 6.Hasil uji Realibilitas (X)

\begin{tabular}{|c|c|c|}
\hline $\begin{array}{c}\text { Cronbach's } \\
\text { Alpha }\end{array}$ & $\begin{array}{c}\text { Cronbach's Alpha Based on } \\
\text { Standardized Items }\end{array}$ & N of Items \\
\hline .908 & .909 & 8 \\
\hline
\end{tabular}

Tabel 7. Hasil uji Realibilitas (Y)

\begin{tabular}{|c|c|c|}
\hline $\begin{array}{c}\text { Cronbach's } \\
\text { Alpha }\end{array}$ & $\begin{array}{c}\text { Cronbach's Alpha Based on } \\
\text { Standardized Items }\end{array}$ & N of Items \\
\hline .775 & .809 & 7 \\
\hline
\end{tabular}

Berdasarkan hasil pengolahan uji realibilitas dari kedua tabel di atas menunjukkan bahwa nilai cronbachalpha tiap atribut pada faktor analisis lebih besar dari 60\% yaitu untuk hasil uji variabel $\mathrm{X}$ adalah 90,9\% dan untuk variabel $\mathrm{Y}$ adalah 80,9\% sehingga semua item faktor analisis tersebut dapat dinyatakan Masuk akal/dapat dipercaya (reliable).

\section{c) Uji Regresi Linier Sederhana}

Tabel 8. Hasil uji Regresi Linier Sederhana

\begin{tabular}{|c|c|c|c|c|c|}
\hline \multirow[b]{2}{*}{ Model } & \multicolumn{2}{|c|}{$\begin{array}{c}\text { Unstandardized } \\
\text { Coefficients }\end{array}$} & \multirow{2}{*}{$\begin{array}{c}\text { Standardized Coefficients } \\
\text { Beta }\end{array}$} & \multirow[b]{2}{*}{$\mathrm{t}$} & \multirow[b]{2}{*}{ Sig. } \\
\hline & B & Std. Error & & & \\
\hline \multirow{2}{*}{$\begin{array}{c}\text { (Constant) } \\
\text { Bank Aceh } \\
\text { (X) }\end{array}$} & 4.260 & 1.507 & & 2.826 & .006 \\
\hline & .684 & .047 & .828 & 14.694 & .000 \\
\hline Depende & able: & $\mathrm{ra}$ & & & \\
\hline
\end{tabular}

Dari tabel di atas, dapat diketahui nilai Constant (a) sebesar 4,260, sedangkan nilai variabel $\mathrm{X}$ sebagai (b / koefisien regresi) sebesar 0,684 , sehingga persamaan regresinya ialah $\mathrm{Y}=4,260+0,684 \mathrm{X}$ yang berarti bahwa nilai konsisten variabel partisipasi adalah 4,260. Berikutnya adalah koefisien regresi $\mathrm{X}$ sebesar 0,684 menyatakan bahwa setiap penembahan $1 \%$ nilai variabel $\mathrm{X}$, maka nilai partisipasi bertambah sebesar o,684. Sebagaimana yang dirincikan tabel di atas bahwa nilai 
koefisien bernilai positif yang berarti arah pengaruh variabel $\mathrm{X}$ terhadap $\mathrm{Y}$ bersifat positif.

\section{d) Uji Hipotesis Uji t}

Tabel 9. Hasil uji Hipotesis

\begin{tabular}{|c|r|r|r|r|r|}
\hline \multirow{2}{*}{ Model } & \multicolumn{2}{|c|}{$\begin{array}{c}\text { Unstandardized } \\
\text { Coefficients }\end{array}$} & Standardized Coefficients & \multirow{2}{*}{ t } & \multicolumn{1}{c|}{ Sig. } \\
\cline { 2 - 6 } & $\mathrm{B}$ & Std. Error & Beta & 2.826 & .006 \\
\hline $\begin{array}{c}\text { (Constant) } \\
\text { Bank Aceh } \\
(\mathrm{X})\end{array}$ & 4.260 & 1.507 & & 14.694 & .000 \\
\cline { 2 - 6 } & .684 & .047 & & .828 & \\
\hline
\end{tabular}

Berdasarkan tabel di atas dengan melihat kolom $\mathrm{t}$ dan sig., menunjukkan hasil bahwa variabel Eksistensi Bank Aceh (X) berpengaruh positif terhadap variabel kesejahteraan masyarakat aceh (Y). Hal ini terlihat dari signifikan variabel $\mathrm{X}$ yaitu $\mathrm{o}, 00<0,05$, dan nilai ttabel $=\mathrm{t}(\alpha / 2 ; \mathrm{n}-1)=\mathrm{t}(0,025 ; 100)=1,98397$. Berarti nilai thitung lebih besar dari ttabel (14,694 > 1, 98397) maka Ho ditolak dan Ha diterima.Sehingga hipotesis dari penelitian ini adalah dimana eksistensi Bank Aceh pasca konversi berpengaruh terhadap kesejahteraan masyarakat Aceh.

\section{Pembahasan}

Berdasarkan hasil dari pengolahan data primer melalui SPSS dengan uji hipotesis, maka ditemukan output bahwa keberadaan PT. Bank Aceh Syariah di Aceh memberikan pengaruh positif bagi kesejahteraan masyarakat. Dengan kata lain, sebagian besar warga aceh berpendapat bahwa pengaruh dari adanya BPD Aceh telah membantu taraf kesejahteraan perekonomian mereka. Namun demikian, hal yang perlu diperhatikan di hasil data ini ialah $64 \%$ dari koresponden mengambil pembiayaan murabahah.Nilai tersebut merupakan nilai terbesar dari hasil penelitian ini untuk akad kerjasama yang dilakukan oleh koresponden. Nilai ini berbanding terbalik dengan akad lainnya yaitu akad mudharabah yang dilakukan hanya 3\%, 2\% persen untuk akad musyarakah, akad qardul hasan $4 \%$ dan $1 \%$ untuk ijarah. Padahal menurut hasil dari pertanyaan yang diajukan oleh peneliti kepada koresponden tentang keinginan mereka untuk mengambil pembiayaan mudharabahah, 64\% dari koresponden menjawab setuju dan sangat setuju.Begitu juga dengan akad qardul hasan dengan jawaban setuju dan sangat setuju untuk melakukan akad tersebut di Bank Aceh Syariah sebanyak $73 \%$. 


\section{Eksistensi Bank Aceh Pasca Konversi Terhadap Kesejahteraan Masyarakat Aceh}

Yoesrizal Muhammad Yoesoef, Khairisma

Merujuk kepada hasil wawancara dengan pegawai bidang pembiayaan Bank Aceh Syariah, menyebutkan bahwa tidak adanya pembiyaan mudharabah dan hanya sedikit nasabah yang memperoleh pembiayaan qardul hasan (Wawancara dengan Zulkhairi, Khairunnisa, Ahmad Firman.Padahal qardul hasan merupakan pembiayaan yang sangat berpengaruh untuk mengurangi angka kemiskinan(Widiyanto, Mutamimah and Hendar, 2011).Namun pembiayaan qardhul hasan belum mendapat perhatian yang serius dari perbankan syariah sebagai perwujudan fungsi sosial perbankan syariah.Begitu juga dengan mudharabah yang sangat membantu masyarakat yang membutuhkan modal untuk usahanya.Sebagaimana menurut Junaidi, dkk menyatakan bahwa produk perbankan syariah lebih berorientasi pada program yang mengandung nilai laba(Junaidi, Lutfiyah and Adnan, 2017).

Dalam hal ini, meskipun murabahah telah menjadi pilihan masyarakat sebagai tolak ukur kesejahteraan mereka dari hasil kuisioner yang diperoleh, tetapi murabahah lebih difokuskan kepada praktek jual beli dan bahkan dalam dunia perbankan sendiri akad ini secara jelas dinamai dengan akad jual beli Murabahah seperti yang diterapkan di Bank Muamalah Kendari(Baktiar et al., 2017). Sehingga dapat disimpulkan bahwa nasabah secara tidak langsung membeli barang dari bank, bukan memperoleh modal untuk usaha mereka. Idealnya, cara untuk mengentaskan kemiskinan ialah dengan peningkatan tingkat pendapatan dengan program-program yang berpihak pada kaum miskin, mencapai distribusi pendapatan yang adil dan memberikan peluang yang sama bagi semua segmen social(Prawoto, 2009). Maka jelaslah di sini bahwa program-program yang dapat membantu pertumbuhan ekonomi rakyat menengah kebawah ialah dengan penyaluran modal melalui mudharabah dan qardul hasan.

\section{Kesimpulan}

Berdasarkan hasil pengujian yang telah dilaksanakan oleh peneliti dalam penelitian ini, maka dapat disimpulkan bahwa Eksistensi Bank Aceh setelah dikonversi menjadi Bank Syariah berpengaruh positif terhadap kesejahteraan masyarakat Aceh.Hal ini dibuktikan dari hasil jawaban 101 orang koresponden. Melalui olah data primer menggunakan SPSS, nilai thitung lebih besar dari ttabel $(14,694$ > 1,98397) maka Ho ditolak dan Ha diterima. Selain itu, Produk pembiayaan yang paling banyak diambil ialah Murabahah yaitu sebanyak 64\%, nilai ini berbanding terbalik dengan akad kerjasama produk lainnya.Namun demikian, nilai positif yang diberikan kepada Bank Aceh Syariah menunjukkan bahwa produk murabahah dapat meningkatkan kesejahteraan masyarakat aceh meskipun sangat banyak masyarakat yang sangat meminati pembiayaan mudharabah dan qardul hasan.Sedangkan, 
Masih ada masyarakat yang kurang memahami istilah-istilah perbankan Syariah.Ini terlihat dari masih adanya koresponden yang memilih pembiayaan mudharabah yang pada dasarnya pembiayaan tersebut tidak disediakan di Bank Aceh Syariah.

\section{DAFTAR PUSTAKA}

Abididn, Z. (2007) Analisis Eksistensial. i. Jakarta: Pt RajaGrafindo Persada.

Ahmad Firman. (10 November 2019). Staff Senior Bagian Pembiayaan PT. BAS Capem Panton Labu, Aceh Utara. Komunikasi pribadi.

Anwar, H. and Said, Z. (2019) 'Persepsi Masyarakat Islam Terhadap Solusi Permodalan Pada Lembaga Keuangan Di Kecamatan Cempa Kabupaten Pinrang (Analisis Ekonomi Islam)', 2.

Bagus, L. (1996) Kamus Filsafat. 1st edn. Jakarta: Gramedia Pustaka Utama.

Baktiar, A. et al. (2017) 'Murabahah Implementation in Islamic Bank (Study at Bank Muamalat Kendari Branch)', IOSR Journal of Economics and Finance, 8(5), pp. 1327. doi: 10.9790/5933-0805011327.

Bank Aceh (2017) 1 Tahun Konversi Bank Aceh Raih 2 Penghargaan Nasional | Bank Aceh. Available at: https://www.bankaceh.co.id/?p=2459 (Accessed: 5 December 2020).

Bank Aceh (2018) Sejarah Singkat | Bank Aceh. Available at: https://www.bankaceh.co.id/?page_id=82 (Accessed: 4 December 2020).

BPS Aceh (2018) Profil Kemiskinan Dan Tingkat Ketimpangan Pengeluaran Penduduk Provinsi Aceh. Available at: https://aceh.bps.go.id/pressrelease/2019/01/15/463/profil-kemiskinan-dantingkat-ketimpangan-pengeluaran-penduduk-provinsi-aceh-september-2018.html. (Accessed: 4 December 2020).

BPS Aceh (2019) Sensus Penduduk 2010 - Penduduk Menurut Wilayah dan Agama yang Dianut | Provinsi Aceh. Available at: https://sp2010.bps.go.id/index.php/site/tabel?tid=321\&wid=1100000000 (Accessed: 12 May 2019).

Farlian, T. and Nuraidar, N. (2017) 'Meretas Reaksi Jalan Panjang Bank Aceh Konversi Syariah', Jurnal Perspektif Ekonomi Darussalam, 3(1), pp. 39-50. doi: 10.24815/jped.v3i1.6991.

Ghozali, I. (2006) Aplikasi Analisis Multivariate dengan Program SPSS. Semarang: Badan Penerbit UNDIP.

Hasan, A. et al. (2010) 'Studi Pengaruh Makro Ekonomi, Capital, Dan Liquidity Terhadap Financial Performance Pada Bank Pembangunan Daerah Di Indonesia Sebelum Dan Setelah Otonomi Daerah'. Available at: www.bi.go.id (Accessed: 4 December 2020).

Jaspers, K. (1995) Philosophy Of Existence. Edited by R. F. Grabau. Phidelphia: University of Pennsilvania Press. doi: 0812276299. 


\section{Eksistensi Bank Aceh Pasca Konversi Terhadap Kesejahteraan Masyarakat Aceh}

Yoesrizal Muhammad Yoesoef, Khairisma

Junaidi, Lutfiyah, Z. and Adnan, M. (2017) 'The Effectiveness of Interest-Free Loan Financing (Qardhul Hasan) As The Social Implementer of Islamic Bank To Reduce Poverty In Surakarta', 6(2), pp. 5-9.

Al Kautsar, S. et al. (2019) 'Pengaruh Konversi Bank Konvensional Menjadi Bank Syariah Terhadap Risiko Kebangkrutan Studi Kasus Pada Bank Aceh', E-Jurnal Ekonomi dan Bisnis Universitas Udayana, 6, p. 550. doi: 10.24843/eeb.2019.vo8.io6.po2.

Kepmendagri (1999) Pedoman Organisasi Dan Tata Kerja Bank Pembangunan Daerah Menteri Dalam Negeri. Available at: https://jdih.bpk.go.id/wpcontent/uploads/2012/03/Kepmendagri-62-19991.pdf (Accessed: 4 December 2020).

Khairunnisa. (15 oktober 2019). Staff bagian Sumber Daya Insani (SDI) Pada PT. BAS kantor Pusat Banda Aceh. Komunikasi pribadi.

Khalidin, B. (2017) 'Pengaruh Suku Bunga Terhadap Kinerja Perbankan Syariah di Provinsi Aceh', 19(1), p. 8.

Kismawadi, E. R. and Al Muddatstsir, U. D. (2018) 'Persepsi Masyarakat Tentang Akan Di Konversikannya Bank Konvensional Ke Bank Syariah Di Aceh Studi Kasus Di Kota Langsa', 2(2), pp. 136-148.

Laporan Tahunan, B. A. (2012) Laporan Tahunan, Bank Aceh. Banda Aceh. Available at: https://www.bankaceh.co.id/wp-content/uploads/2013/o6/Laporan-TahunanAnnual-Report-2012.pdf (Accessed: 6 December 2020).

Laporan Tahunan, B. A. (2017) Laporan Tahunan Annual Report 2017. Banda Aceh.

Laporan Tahunan, B. A. (2018) Laporan Tahunan Annual Report 2018. Banda Aceh.

ModusAceh.co (2019) 'Dua Tahun Konversi Tembus Rp 23 Triliun', 5 March. Available at: https://modusaceh.co/news/dua-tahun-konversi-tembus-rp-23-triliun/index.html (Accessed: 4 December 2020).

Mutia, R. and Aswadi, K. (2017) 'Hakikat Fungsi Intermediasi Perbankan Syariah: Studi Kasus Di Kota Banda Aceh', Jurnal Ekonomi dan Kebijakan Publik Indonesia, 4(2), pp. 118-135.

OJK (2019) Daftar Alamat Kantor Pusat Bank Umum Dan Syariah. Available at: https://www.ojk.go.id/id/kanal/perbankan/data-dan-statistik/Pages/DaftarAlamat-Kantor-Pusat-Bank-Umum-Dan-Syariah.aspx (Accessed: 4 December 2020).

Peraturan Bank Indonesia (2006) Peraturan Bank Indonesia Nomor: 8/3/Pbi/2006 Tentang Perubahan Kegiatan Usaha Bank Umum Konvensional Menjadi Bank Umum Yang Melaksanakan Kegiatan Usaha Berdasarkan Prinsip Syariah Dan Pembukaan Kantor Bank Yang Melaksanakan Kegiatan Usaha Berdasarkan Prin. Jakarta.

Prawoto, N. (2009) 'Memahami Kemiskinan Dan Strategi Penanggulangannya', Jurnal Ekonomi dan Studi Pembangunan, 9(1), pp. 56-68. 
Purwanto, P. (2018) 'Fungsi Intermediary Bank Aceh Setelah Melakukan Konversi Menjadi Bank Umum Syariah', Ihtifaz: Journal of Islamic Economics, Finance, and Banking, 1(1), p. 137. doi: 10.12928/ijiefb.v1i1.248.

Sabrina and Majid, M. S. A. (2019) 'Mengapa Pembiayaan Berbasis Bagi Hasil Rendah Di Perbankan Syariah? (Suatu Kajian Menggunakan Pendekatan Grounded Theory)', Jurnal Ilmiah Mahasiswa Ekonomi Islam, 1(1), pp. 51-70.

Saputra, A. (2019) 'Peringkat Kemiskinan di Sumatera: Aceh Tertinggi, Kepri Terendah', detikNews, 16 January. Available at: https://news.detik.com/berita/d4387144/peringkat-kemiskinan-di-sumatera-aceh-tertinggi-kepri-terendah (Accessed: 4 December 2020).

Sugono, D. et al. (2008) Kamus Bahasa Indonesia. Jakarta: Pusat Bahasa.

Suherman, A. (2018) SKRIPSI ANALISIS KUALITAS PELAYANAN DENGAN MODEL CARTER DAN PENGARUHNYA TERHADAP KEPUASAN NASABAH (Studi Pada PT Bank Aceh Syariah KC Banda Aceh). Universitas Islam Negeri Ar-Raniry. Available at: https://repository.ar-raniry.ac.id/id/eprint/6683/1/AGAM SUHERMAN.pdf (Accessed: 5 December 2020).

Utami, D. A. R. (2017) Pengaruh Persepsi Masyarakat Tentang Perbankan Syariah Terhadap Minat Menabung Di Bank Syariah (Studi Kasus Pada Masyarakat Muslim Kauman Wijirejo Pandak Bantul).

Widiyanto, Mutamimah and Hendar (2011) 'Effectiveness of Al Qard Al Hasan Financing As a Poverty Allevation Model', Journal of Islamic Economics.

Yulianti, R. (2015) 'Pengaruh Minat Masyarakat Aceh terhadap Keputusan Memilih Produk Perbankan Syariah di Kota Banda Aceh', Jurnal Dinamika Akuntansi dan Bisnis, 2(1), pp. 14-28. doi: 10.24815/jdab.v2i1.3599.

Zulkhairi. (10 Juni 2019). Staff Senior Bagian Pembiayaan PT. BASKC. Merdeka Lhokseumawe. Komunikasi pribadi. 